\title{
PEDAGOGIC ABILITIES OF MATHEMATICS EDUCATION STUDENTS IN LEARNING DESIGN
}

\author{
Eka Widyawati \\ ${ }^{1}$ University of Borneo Tarakan, Jl. Amal Lama No.1, Tarakan \\ eka.adel48@gmail.com
}

\begin{abstract}
This study aims to analyze student teacher candidate pedagogical content knowledge (PCK) in designing learning. This research was conducted on seventh-semester students who had taken microteaching courses in the Mathematics Education Department. The research design used is descriptive research with an ex post facto approach. Data collection was carried out using PCK observation sheets with two aspects: analysis in designing learning and learning management. The research results obtained based on the percentage of students' ability to make planning amounted to $76.81 \%$ and the ability to manage learning by $80 \%$.
\end{abstract}

Keywords : (PCK, Teacher Candidates, Learning Design)

\section{PRELIMINARY}

Pedagogic competence concerns a teacher's ability to understand students' characteristics or abilities in various ways. The primary way is to understand students through student cognitive development, designing learning and implementing learning, and evaluating learning outcomes and student development. To achieve this competency, Mathematics Education students are equipped to design learning through planning and developing mathematics learning courses.

The main competencies that teachers must possess can be instilled starting from the student level (prospective teachers). The ability of professional teachers and havingto master content and its integration must also have unique understanding and abilities to combine material knowledge, curriculum, learning, teaching, and students, one of which is by understanding PCK (Pedagogical Content Knowledge). Pedagogical Content Knowledge (PCK is a combination of content knowledge and pedagogical knowledge). Rosnita stated that pedagogical content knowledge (PCK) is one of preparing teacher candidates' standards [1](Yulianti and Pratiwi, 2017). Pedagogical Content Knowledge (PCK), according to Mishra and Koehler [2](Abbit, 2011), is knowledge about pedagogy, practice, learning, learning process planning, and the right method for teaching material. In this case, PCK is 
transforming knowledge (Content Knowledge) by using/embracing pedagogical knowledge so that the subject matter taught is teachable and accessible to students.

Furthermore, according to [3]Agustina (2015), PCK in learning is manifested in various learning approaches for materials with different content characteristics. Educators understand content and pedagogy, but educators can understand the process of transforming knowledge to students based on the teacher's understanding of pedagogical and other sciences related to education and students.

The ability of prospective teacher students in designing Mathematics learning is beneficial for students to plan, implement, and evaluate learning properly when they enter the world of schooling. Competencies that students must master are also listed in learning outcomes, namely, developing learning plans manifested in one of the mathematics learning development and planning courses. Based on the results of [4]Widyawati's research (2017), it shows that the ability of students of the mathematics education study program in developing learning devices is in a suitable category, obtained by a percentage of $71.51 \%$. Based on the description of the above problems, a study is needed to "Analyze the pedagogical content knowledgeability Prospective Teacher Students in Learning Design."

\section{METHOD}

This type of research is a quantitative descriptive study using an ex post facto approach. According to [5]Widarto (2013), the ex post facto approach aims to find causes that allow changes in behavior, symptoms, or phenomena caused by an event, behavior, symptom, or phenomenon caused by an event, behavior, or things that cause changes in the independent variable as a whole-already occurred.

The instrument used in the study was the PCK observation sheet instrument in 2 aspects (learning design and learning management).

\section{RESULTS AND DISCUSSION}

\subsection{Description of the ability to design}

\section{learning in student-teacher candidates}

The ability to design learning by prospective mathematics education teacher students is seen from four indicators. The first indicator contains the identity, competence, and learning teaching materials written by students. The second indicator is learning resources, learning media, and learning 
methods. The third indicator is a scenario of learning activities designed by student teacher candidates. The fourth indicator is the assessment of learning carried out. This assessment instrument is in the form of a lecturer assessment questionnaire on the student's ability to design learning devices on a scale of 1 to 5 .

Microteaching is more emphasized on instructional rather than teaching; teaching is more formal and only exists in teachers and students in class/school. The word learning does not only exist in the context of teachers with students in class formally. but also includes student learning activities outside the classroom which may not be attended by the teacher physically [6](Arifin, 2012)

Identity and competency indicators contain three aspects. The first aspect is the completeness of identity; learning identity is declared complete if it contains subjects, education level, class, semester, time allocation, and implementation date. The second aspect includes Core Competencies (KI), Basic Competencies (KD), and indicators according to SI. The third aspect is that the learning indicators must formulate the writing of learning objectives.

The second indicator for assessing the ability to design learning is the learning activity scenario design developed, which must refer to the scientific approach. Learning activities are divided into three main steps. A teacher's knowledge in providing learning situations helps students understand the content of scientific facts [7](Loughran, 2012). The first step is the activity of opening lessons. The activity of opening learning begins with a clear and correct apperception design. This is followed by how to motivate students clearly stated in the scenario. The second activity is the core activity / main activity in learning. In this activity, it must be formulated, in detail, and correctly regarding the flow of the stages of achieving KD, write down the time allocation at each learning stage. The learning stages allow students to interact with friends, teaching materials, teachers, or the learning environment. The last stage in the learning scenario is the activity to close learning. Prospective teacher students must be able to design learning assessments according to their competencies. This conformity is reflected in the assessment tool/instrument's suitability with KD. The assessment instrument covers all learning indicators, and the last indicator for the assessment aspect is the answer key, and the scoring guideline is clearly stated. 
Assessment of aspects of students' abilities in making lesson plans is assessed with a Likert scale rating range 1-5. Based on the design analysis developed by students who are prospective mathematics education teachers, the percentage of achievement is 76.81\%. This percentage shows that prospective mathematics education teacher students' ability to make learning designs is in a suitable category seen from the accuracy and suitability of learning indicators. This is consistent with the results of research [8](Bahari, 2020), showing that of the four indicators of the teacher's ability in lesson planning, three indicators show that the teacher has a good understanding, but the indicators determine the learning strategy based on the characteristics of students, the competencies to be achieved and the material teaching, it appears that the teacher's ability is still in the moderate category.

\subsection{Description of the ability to manage}

learning in the classroom for prospective teacher students.

The ability of prospective mathematics education teaches students to manage learning based on four indicators that appear during the implementation of microteaching. Assessment of ability is carried out by observing students' appearance in teaching, managing simulation learning with limited teaching practices with the number of students is ten people. Each student is allocated the same time for 15 minutes to carry out learning according to the learning design, including preliminary activities, core activities, and closing activities. In the implementation of microteaching, students can use language that is easy to understand and adjust the time. Each component in learning appears in the learning process carried out in microteaching practice. Students must look like a teacher in teaching.

One of the necessary teaching skills in managing learning is opening lessons as the first indicator. The activity of opening the lesson begins with students' physical and psychological preparation for learning by motivating so that it attracts students 'attention and increases students' curiosity about the material presented. The second aspect is the provision of apperception by linking the material with students 'daily lives and extracting information from students' prior knowledge.

The ability of prospective teachers to carry out the core of learning is the second indicator. This ability is based on 
the use of appropriate learning methods, the accuracy of the material/concept presented, mastery of the material during learning, and the use of learning media. The learning method chosen by the prospective teacher should adapt to the characteristics of the learning material and can activate student learning activities. The concepts conveyed by prospective teachers must be meaningful to students so that students have a correct understanding of the meaning of the concepts that have been conveyed. Mastery of prospective teachers' competence is measured in the learning process, such as providing adequate feedback on each student's performance and student opinions. The next aspect is the use of instructional media. They are learning media as an intermediary for communication between teachers and students to streamline communication and interaction between teachers and students in the learning process during microteaching. Learning media should be used effectively by involving students during the planned teaching process.

The third indicator is carrying out activities to close the lesson. Closing lessons is the last activity in the learning process. The closing activity is carried out not only by saying greetings as a sign of the end of learning, by reviewing the material that has been delivered, and conducting an evaluation of the subject matter that has been delivered. Assessment of aspects of the student teacher's ability in managing learning is assessed using a Likert scale with an assessment range of 1-5. Based on the analysis of the implementation of learning carried out by student teacher candidates, the achievement percentage was $80 \%$. The percentage shows that prospective teacher students' ability in managing/implementing learning is in a suitable category.

\section{CONCLUSION}

Based on the results of the analysis and discussion that has been presented, the following conclusions can be drawn:

1. The percentage of student-teacher candidates' ability in making plans is $76.81 \%$ in the excellent category.

2. The percentage of student-teacher candidates' ability in managing learning is $80 \%$ in the excellent category.

\section{REFERENCES}

[1] N. P. Erni Yulianti, "Identifikasi Pedagogical Content Knowledge (PCK) Mahasiswa Calon Guru IPA FMIPA Universitas Negeri Malang Tahun 2016 Melalui Kegiatan Kuliah 
Praktik Lapangan (KPL) Berbasis Lesson Study," J. Pembelajaran Sains, vol. 1, pp. 27-34, 2017.

[2] J. T. Abbitt, "Measuring technological pedagogical content knowledge in preservice teacher education: A review of current methods and instruments," J. Res. Technol. Educ., vol. 43, no. 4, pp. 281-300, 2011, doi: 10.1080/15391523.2011.10782573.

[3] P. Agustina, "Analisis Technological Pedagogical and Content Knowledge (TPACK) Mahasiswa Calon Guru Biologi FKIP Universitas Muhammadiyah Surakarta.," 2015.

[4] E. Widyawati, "Profil Kemampuan Mahasiswa Merancang Perangkat Pembelajaran.," Edukasia, 2018.

[5] Widarto, "PENELITIAN EX POST FACTO, Modul Pelatihan Metodologi Penelitian Pendidikan," 2013, [Online]. Available: http://staff.uny.ac.id/sites/default/files /pengabdian/dr-widarto$\mathrm{mpd} /$ ppenelitian-ex-post-facto.pdf.

[6] Z. Arifin, Evaluasi Pembelajaran:

Prinsip, Teknik Prosedur. Jakarta: PT Remaja Rosdakarya., 2012.

[7] M. Loughran, J., Amanda, B., \& Pamela, "Understanding and Developing Science Teacher's Pedagogical Content Knowledge," Sense Publ., pp. 1-235, 2012, doi: 10.1007/978-94-6091-821-6.

[8] Bahari, "Pedagogical Knowledge: Analisis Kemampuan Pedagogik Guru IPS dalam Merancang Pembelajaran. Indonesian Journal of Social Science Education," J. Soc. Sci. Educ., vol. 2(1), pp. 33-39, 2020. 